\title{
Quality changes in the lotus root frozen under different conditions
}

\author{
Seung-Jong Park, Kyung Bin Song* \\ Department of Food Science and Technology, Chungnam National University, Daejeon 305-764, Korea
}

\section{냉동조건에 따른 연근의 품질 변화}

\author{
박승종 · 송경빈 ${ }^{*}$ \\ 충남대학교 식품공학과
}

\begin{abstract}
This study was performed to optimize the preparation of frozen lotus roots. Prior to freezing, an optimal blanching condition at $100^{\circ} \mathrm{C}$ for $5 \mathrm{~min}$ was established, based on the microbial growth, texture, total phenolic content (TPC), and sensory evaluation results. The blanched samples were then frozen under various freezing conditions $\left(-20^{\circ} \mathrm{C}\right.$ in a freezer for $2 \mathrm{hr},-70^{\circ} \mathrm{C}$ in a gas nitrogen convection chamber for $7 \mathrm{~min}$, and $-196^{\circ} \mathrm{C}$ in liquid nitrogen for $20 \mathrm{sec}$ ), and their qualities after thawing were determined. The scanning electron microscopic analysis indicated that the microstructure of the sample frozen at $-70^{\circ} \mathrm{C}$ was similar to that of the control sample, compared with the other freezing conditions $\left(-20\right.$ and $\left.-196^{\circ} \mathrm{C}\right)$. The antioxidant activities of the frozen samples decreased compared to those of the control, but there was no significant $(p<0.05)$ difference among the treatments. In terms of TPC, the samples frozen at -70 and $-196{ }^{\circ} \mathrm{C}$ had significantly $(p<0.05)$ higher values than the sample frozen at $-20^{\circ} \mathrm{C}$. In addition, the drip loss of the sample frozen at $-20^{\circ} \mathrm{C}$ was higher than those of the other frozen samples. These results suggest that freezing at $-70^{\circ} \mathrm{C}$ in a gas nitrogen convection chamber can be an optimal freezing method of producing high-quality frozen lotus roots.
\end{abstract}

Key words : lotus root, freezing, quality, blanching

\section{서 론}

연근(Nelumbo nucifera Gaertn)은 주성분인 전분 외에도, 칼슘, 철, 아연 등 미네랄과 polyphenol 화합물, tannic acid 등 생리활성물질 함유량이 높아 항고혈압, 항암, 항산화, 항스트레스 효과가 있다고 알려져 있다(1-3). 그러나 연근 의 경우, 세정, 박피, 절단 등의 가공공정 중에 외부환경으로 부터 미생물에 의한 오염이나 효소에 의한 갈변현상으로 품질저하가 빠르게 진행되기에, 수확 후 가공 저장 중 연근 의 품질을 유지하기 위한 연구들이 필요하다(4-6). 특히, 미생물학적 안전성 확보 및 저장성을 높이기 위한 전처리

*Corresponding author. E-mail : kbsong@cnu.ac.kr Phone : 82-42-821-6723, Fax : 82-42-825-2664

Received 11 September 2014; Revised 10 November 2014; Accepted 10 November 2014.

Copyright (c) The Korean Society of Food Preservation. All rights reserved.
기술로써 blanching을 보편적으로 사용하고 있으나 $(7,8)$, blanching은 맛, 향, 질감 등 관능적 품질저하 및 영양소 손실을 야기한다고 알려져 있어 $(9,10)$, 연근의 관능적, 영양 적 품질변화를 최소화 할 수 있는 최적의 blanching 조건을 설정하는 것이 필요하다.

최근 생활수준 향상, 식품시장 변화 등으로 인해 즉석섭 취식품 형태의 가공 연근이나 냉동연근 등 신선편이 식품의 수요가 증가하고 있는데(11), 연근의 홍수 출하 시 가격 안정을 위하여 고품질의 냉동연근을 생산하기 위한 연구가 필요한 실정이다. 냉동은 수확 후 채소의 이화학적 특성을 장기 보존하기 위한 목적으로 널리 사용되고 있으나, 얼음 결정 형성에 따른 손상, 조직의 균열 등 물리적 변화를 야기 한다(12).

찬 공기의 순환을 이용하여 $-20^{\circ} \mathrm{C}$ 에서 식품을 동결시키 는 방법은 일반적으로 보편화되어 있으나, 조리 시 해동할 경우 조직감 저하나 수분손실 등 품질이 저하되어 이를 대체할 수 있는 방법으로 급속냉동(cryogenic freezing) 방법 
이 이용되는데, 급속냉동은 $-20^{\circ} \mathrm{C}$ 에서의 냉동에 비하여 조 직 손상이 적어 품질을 잘 유지하는 것으로 보고되었다(13). 특히, 최근 gas nitrogen convection chamber를 이용한 -7 $0^{\circ} \mathrm{C}$ 에서의 과채류의 냉동에 관한 연구들 $(14,15)$ 에서, 기존 $-20^{\circ} \mathrm{C}$ 에서의 냉동이나 액체질소를 이용한 $-196^{\circ} \mathrm{C}$ 에서의 냉동보다 고품질을 유지한다고 보고되었다.

따라서 본 연구에서는 냉동연근의 제조에 있어서 최적 전처리 공정 및 냉동조건을 수립하고자, blanching 조건의 확립 및 여러 냉동조건(-20, $\left.-70,-196^{\circ} \mathrm{C}\right)$ 에서 냉동된 연근의 품질을 비교, 분석하였다.

\section{재료 및 방법}

\section{실험재료}

본 실험에 사용된 연근은 2014년 대전에서 구입한 것으 로, 외부에 손상이 없고 크기가 일정한 것을 선별하여 멸균 처리한 칼을 사용하여 두께 $1 \mathrm{~cm}$ 로 자른 것을 실험에 사용 하였다.

\section{냉동 전처리}

냉동 전 blanching 조건으로 $100^{\circ} \mathrm{C}$ 에서 $1,3,5$ 분 처리하였 다. 항온수조에 물 $10 \mathrm{~L}$ 를 채워 $100^{\circ} \mathrm{C}$ 에서 시료 $(500 \mathrm{~g})$ 를 $1,3,5$ 분 각각 데치고 찬물에 1 분 동안 냉각하여 특별히 제작된 spinner에서 90초 동안 물기를 제거한 후, air-tight plastic bag에 각각 포장하였다.

\section{냉동조건}

시료의 냉동은 기존 수행하였던 Park 등(15)의 방법에 따라 수행하였다. 냉동 전처리로 $100^{\circ} \mathrm{C}$ 에서 5 분 동안 blanching 한 연근을 air-tight plastic bag에 각각 $500 \mathrm{~g}$ 씩 포장 한 후, 3 가지 냉동조건 $\left(-20,-70,-196^{\circ} \mathrm{C}\right)$ 에서 냉동하였다. $-20^{\circ} \mathrm{C}$ 는 freezer(SR644CC, Samsung, Seoul, Korea)에서 2시 간, $-70^{\circ} \mathrm{C}$ 는 gas nitrogen convection chamber(Dream and Field Co., Nonsan, Korea)에서 7 분, $-196^{\circ} \mathrm{C}$ 는 액체질소에 20초 동안 dipping하여 각각 냉동시키고, 각 냉동된 연근은 $-20^{\circ} \mathrm{C}$ 에서 실험 시 까지 냉동 보관하였다. 냉동연근의 품 질변화를 비교, 분석하기 위하여, 각 냉동조건에서 냉동된 연근 시료를 $4{ }^{\circ} \mathrm{C}$ 일정 온도에서 over night 방치하여 해동한 후 품질을 측정하였다.

\section{Scanning electron microscopy(SEM) 관찰}

냉동연근의 구조는 전자주사현미경(LEO 1455VP, Angstrom Scientific Inc., Cambridge, England)를 이용하여 $15 \mathrm{kV}$ 에서 단면을 200 배율로 촬영하였다.

미생물 수 측정

연근 시료 $20 \mathrm{~g}$ 과 $0.1 \%$ 멸균 펩톤수 $180 \mathrm{~mL}$ 를 멸균 $\mathrm{bag}$ 에
넣고 Stomacher(MIX 2, AES Laboratoire, Combourg, France)로 3분간 균질화시켰다. 균질화 된 시료를 $0.1 \%$ 멸 균 펩톤수로 10 배수 연속 희석 한 후 각각의 배지에 분주하 였다. 미생물 수 계수를 위해 PetrifilmTM(Aerobic count plate, Yeast and mold count plate, Coliform count plate, Staph express count plate, $3 \mathrm{M}$, St. Paul, MN, USA) 배지를 사용하 였으며, 총 호기성 세균은 $37^{\circ} \mathrm{C}$ 에서 48 시간, 효모 및 곰팡이 는 $25^{\circ} \mathrm{C}$ 에서 120 시간, 대장균군은 $37^{\circ} \mathrm{C}$ 에서 24 시간, 포도상 구균은 $37^{\circ} \mathrm{C}$ 에서 24 시간 동안 배양한 후 형성된 colony를 계수하였다. 3 회 반복 실험 하였으며, 검출된 미생물 수는 $\log \mathrm{CFU} / \mathrm{g}$ 으로 나타내었다.

\section{물성 측정}

연근의 경도는 직경 $5.0 \mathrm{~mm}$ probe가 장착된 texture analyzer(TA-XT2, Stable Microsystem Ltd., Godalming, UK) 로 측정하였다. Texture profile analysis(TPA) test는 pre-speed $2.0 \mathrm{~mm} / \mathrm{s}$, test speed $5.0 \mathrm{~mm} / \mathrm{s}$, post-speed $5.0 \mathrm{~mm} / \mathrm{s}$ 의 속도로 연근 두께의 $60 \%$ 깊이까지 도달했을 때 얻은 최대값을 hardness $(\mathrm{g})$ 로 나타내었다. 실험은 $20^{\circ} \mathrm{C}$ 에서 진행 하였으며 3회 반복 실험하였다.

수분손실률 측정

연근의 수분손실률 측정은 시료 $10 \mathrm{~g}$ 을 $4^{\circ} \mathrm{C}$ 에서 24 시간 해동한 후, 해동 전후 무게의 차이를 해동 전 냉동된 시료의 무게에 대한 백분율 $(\%)$ 로 나타내었으며, 3회 반복실험을 실시하였다.

\section{총 페놀 함량 측정}

연근의 총 페놀 함량은 Rumbaoa 등(16)의 방법을 변형하 여 Folin-Ciocalteu's phenol reagent를 이용하여 측정하였다. 연근을 $80 \%$ 메탄올에 $1: 20(\mathrm{w} / \mathrm{v})$ 의 비율로 넣고 24 시간 동안 추출한 다음, 추출액을 여과지(Whatman No. 1)를 이용해 여과한 후 실험에 사용하였다. 추출액 $100 \mu \mathrm{L}$ 에 증류수 $1.5 \mathrm{~mL}, 2 \mathrm{~N}$ Folin-Ciocalteu's phenol reagent $100 \mu \mathrm{L}$ 를 첨가 하여 혼합한 후, $20 \%$ sodium carbonate 용액 $300 \mu \mathrm{L}$ 를 넣고 1 시간 동안 반응시켰다. 반응 후 분광광도계(UV-2450, Shimadzu Co., Kyoto, Japan)를 이용하여 $765 \mathrm{~nm}$ 에서 흡광 도를 측정하였고, 표준검 량선은 gallic acid를 사용하였다. 연근의 총 페놀 함량은 3 회 반복 실험하여 $\mathrm{mg} \mathrm{GAE} / 100$ $\mathrm{g}$ 으로 표시하였다.

\section{항산화능 측정}

시료의 추출은 동결건조기를 이용하여 수분을 제거한 후 분쇄 과정을 거쳐 분말로 만든 후, 시료 $20 \mathrm{~g}$ 을 $70 \%$ ethanol $400 \mathrm{~mL}$ 에 혼합한 후 stirrer에서 $160 \mathrm{rpm}$ 으로 12시간 동안 추출하였다. 추출액은 여과지(Whatman No. 2)에서 여과한 후, $50^{\circ} \mathrm{C}$ 항온수조에서 감압농축하여 동결건조한 
분말을 항산화능 실험에 사용하였다.

1,1-diphenyl-2-picryl-hydrazyl(DPPH) free radical scavenging activity 분석은 $\mathrm{Kim}$ 등(17)의 방법을 변형하여 측정하였다. 시료 $1 \mathrm{~mL}(10 \mathrm{mg})$ 에 $0.1 \mathrm{mM} \mathrm{DPPH} 5 \mathrm{~mL}$ 을 혼합하여 균질 화한 후, 암소에서 30 분 반응시켜 분광광도계를 이용하여 $517 \mathrm{~nm}$ 에서 흡광도를 측정하였다. 실험은 3회 반복 측정하 여 scavenging activity(\%)로 나타내었다.

Ferric reducing antioxidant power(FRAP) 분석은 Benzie 등(18)의 실험방법을 변형하여 측정하였다. Sodium acetate buffer(300 mM, pH 3.6)에 용해시킨 $10 \mathrm{mM} \mathrm{2,4,6-}$ tripyridyl-s-trizine(TPTZ)와 $20 \mathrm{mM} \mathrm{FeCl}$ 용액을 제조한 뒤 $10: 1: 1(\mathrm{v}: \mathrm{v}: \mathrm{v})$ 의 비율로 혼합하여 균질화한 FRAP 시약을 사용하였고 분광광도계를 이용하여 $593 \mathrm{~nm}$ 에서 측정하였 다. 시료 $150 \mu \mathrm{L}(10 \mathrm{mg} / \mathrm{ml})$ 와 FRAP 시약 $4.5 \mathrm{~mL}$ 을 첨가하 여 10 초간 균질화한 후 측정한 흡광도와 $37^{\circ} \mathrm{C}$ 물에서 4 분간 반응시킨 후 측정한 흡광도 차이를 gallic acid 를 이용하여 $\mathrm{mg} \mathrm{GAE} / \mathrm{g}$ sample로 나타내었으며 3회 반복 실험하였다.

\section{관능평가}

연근의 최적 blanching 조건을 설정하기 위해 전문적으로 훈련된 panel 10명(24 29세, 남녀 각5명)이 시료의 신선도 (freshness), 색도(color), 외관적 상태(appearance), 냄새 (odor), 종합적 기호도(overall acceptance)에 대한 관능검사 를 실시하였다. 각 시료에 대한 평점은 9점 기호 척도법(9 8 점, 매우좋음; 7 6점, 좋음; 5 4점, 보통; 3 2점, 나쁨; 1점, 매우나쁨)으로 나타내었다.

\section{통계처리}

본 실험의 유의성 검정을 위해 SAS(Statistical Analysis System, 8.1, SAS Institute Inc., Cary, NC, USA) 프로그램을 사용하여 $\mathrm{p}<0.05$ 수준에서 Duncan's multiple range test 방법 을 사용하여 통계처리 하였으며, 실험결과는 평균표준편 차로 나타내었다. 모든 실험의 측정값은 신뢰성을 확보하 기 위하여 3회 반복하였다.

\section{결과 및 고찰}

\section{냉동 전 blanching 조건}

연근의 미생물 수 측정 결과에서 볼 수 있듯이(Table 1), 수확 후 연근에서 식중독을 유발할 수 있는 포도상구균이 검출됨에 따라 blanching이 필요함을 보여준다. 연근의 수 확 중에 토양으로부터 미생물 오염이나 수세 및 박피 등의 가공공정에서 기계적인 상처, 칼 등에 의한 교차오염으로 세균 등에 의한 오염 가능성이 높아 $(19,20)$, 미생물학적 안 전성 확보를 위한 전처리로써 blanching이 필요하다.

수확 후 blanching 하지 않은 연근의 총 호기성 세균은
$4.64 \log \mathrm{CFU} / \mathrm{g}$ 이었고, 이는 Chang 등(21)이 세척수 온도에 따른 신선편이 연근의 품질 변화를 살펴본 연구에서 열처리 하지 않은 연근의 초기 미생물 수가 $5.61 \log \mathrm{CFU} / \mathrm{g}$ 이었다 는 보고와 유사한 결과를 나타내었다. 반면에 blanching을 1,3 분 각각 처리했을 때 $2.42,2.14 \log \mathrm{CFU} / \mathrm{g}$ 으로 2.22 , $2.50 \log \mathrm{CFU} / \mathrm{g}$ 의 감균 효과를 보였고, 또한 5 분 blanching한 처리군에서는 총 호기성 세균이 검출되지 않아 blanching 처리 시간에 따른 유의적인 차이가 있었다(Table 1). 이러한 결과는 $80^{\circ} \mathrm{C}$ 에서 15 초 동안 blanching한 오이 절임에 있어 서 대조구와 비교했을 때 $2.43 \log \mathrm{CFU} / \mathrm{g}$ 로 감소했다는 연구 보고와 시료는 다르지만 유사한 경향을 나타내었다 (22). 효모 및 곰팡이수는 수확 후 연근이 $3.45 \log \mathrm{CFU} / \mathrm{g}$ 이 었고, 5 분 blanching 처리군에서 $2.06 \log \mathrm{CFU} / \mathrm{g}$ 로 $1.39 \mathrm{log}$ $\mathrm{CFU} / \mathrm{g}$ 의 감균효과를 나타내었다. 대장균군은 대조구의 미 생물 수가 $3.19 \log \mathrm{CFU} / \mathrm{g}$ 이었고, 1, 3분 동안 blanching한 처리군은 $2.08,1.81 \log \mathrm{CFU} / \mathrm{g}$ 로 대조구와 비교했을 때 $1.11,1.38 \log \mathrm{CFU} / \mathrm{g}$ 의 감균효과를 나타냈으며, 5 분 처리구 에서는 검출이 되지 않아 유의적인 차이를 보였다. 포도상 구균의 경우, 1 분 blanching 한 처리군이 $0.32 \log \mathrm{CFU} / \mathrm{g}$ 의 감균효과를 보인 반면에, 3,5 분 처리군에서는 포도상구균 군이 검출되지 않았다. 이와 같이 blanching은 식품의 미생 물학적 안전성을 증대하기 위한 효과적인 방법이라고 생각 된다(23,24).

연근의 총 페놀 함량은 $46 \mathrm{mg} \mathrm{GAE} / 100 \mathrm{~g}$ 에서 blanching 후 38 43 mg GAE/100 g으로 blanching 시간이 길어짐에 따라 감소하는 경향을 보였는데(Table 1), 이와 같은 결과는 시금치를 끓는 물에서 각각 10,15 분 처리한 뒤 대조구와 비교했을 때 총 페놀 함량이 감소했다는 보고(26)와 유사하 였다.

Blanching한 연근의 물성을 분석하기 위해 연근의 경도, 점착성, 씹힘성, 질김성을 측정하였다(Table 2). 열처리하지 않은 연근의 경도가 $4,590 \mathrm{~g}$ 인 반면에, blanching 처리 후 $3,011 \sim 3,643 \mathrm{~g}$ 으로 $21 \sim 34 \%$ 의 감소를 보였다. 이러한 결과 는 blanching 시간이 길어짐에 따라 연근의 조직이 약해지 는 것을 나타내는 것으로, 도라지를 blanching한 후 경도가 감소하는 결과와 유사하였다(7). 점착성은 대조구와 비교 했을 때, $-88 \mathrm{~g} \cdot \mathrm{s}$ 까지 증가하는 경향을 보였으나, 3,5 분 처리구간에서는 유의적인 차이를 보이지 않았다. 씹힘성과 질김성은 blanching 시간이 길어질수록 감소하는 경향을 보였다. 이와 같은 물성 측정 결과에서, blanching 시간이 길어질수록 점착성를 제외하고 모두 감소하는 경향을 보였 지만, 3,5 분 처리구간에는 경도를 제외하고는 유의적인 차이를 보이지 않았다. Lee(25)는 채소류의 blanching 처리 시, 높은 온도에서의 blanching 처리는 펙틴의 열분해에 의 해서 조직이 연화되어 crispness, hardness, toughness 같은 물성이 모두 감소한다고 보고하여 본 연구결과와 유사하 였다. 
Table 1. Microbial populations and total phenolic contents of the blanched lotus root samples

\begin{tabular}{|c|c|c|c|c|c|}
\hline \multirow{2}{*}{ Samples } & \multicolumn{4}{|c|}{ Microorganisms (log CFU/g) } & \multirow{2}{*}{$\begin{array}{l}\text { Total phenolic content } \\
\text { (mg GAE/100 g) }\end{array}$} \\
\hline & Total aerobic bacteria & Yeast and molds & Coliform & Staphylococcus & \\
\hline Control $^{1)}$ & $4.64 \pm 0.04^{\mathrm{a} 2)}$ & $3.45 \pm 0.05^{\mathrm{a}}$ & $3.19 \pm 0.04^{\mathrm{a}}$ & $1.68 \pm 0.17^{\mathrm{a}}$ & $46.16 \pm 1.67^{\mathrm{a}}$ \\
\hline Blanching $1 \mathrm{~min}$ & $2.42 \pm 0.10^{\mathrm{b}}$ & $2.38 \pm 0.09^{b}$ & $2.08 \pm 0.23^{b}$ & $1.36 \pm 0.10^{b}$ & $43.03 \pm 0.80^{\mathrm{b}}$ \\
\hline $3 \min$ & $2.14 \pm 0.15^{\mathrm{c}}$ & $2.37 \pm 0.07^{b}$ & $1.81 \pm 0.26^{\mathrm{b}}$ & $\mathrm{ND}$ & $38.81 \pm 0.26^{\mathrm{C}}$ \\
\hline $5 \min$ & $\mathrm{ND}^{3)}$ & $2.06 \pm 0.20^{c}$ & $\mathrm{ND}$ & $\mathrm{ND}$ & $38.40 \pm 0.21^{\mathrm{c}}$ \\
\hline
\end{tabular}

${ }^{1)}$ No blanching.

${ }^{2)}$ Values in a column followed by different letters are significantly $(\mathrm{p}<0.05)$ different by Duncan's multiple range test.

${ }^{3}$ Not detected.

Table 2. Changes in texture of the blanched lotus root samples

\begin{tabular}{|c|c|c|c|c|}
\hline \multirow[b]{2}{*}{ Samples } & \multicolumn{4}{|c|}{ Texture } \\
\hline & Hardness (g) & $\begin{array}{l}\text { Adhesiveness } \\
(\mathrm{g} \cdot \mathrm{s})\end{array}$ & Chewiness & Gumminess \\
\hline Control $^{1)}$ & $4590.41 \pm 89.25^{\left.5^{2}\right)}$ & $-7.12 \pm 0.28^{\mathrm{a}}$ & $413.84 \pm 42.75^{\mathrm{a}}$ & $1091.00 \pm 56.96^{\mathrm{a}}$ \\
\hline $\begin{array}{l}\text { Blanching } \\
1 \mathrm{~min}\end{array}$ & $3643.35 \pm 33.23^{b}$ & $-54.72 \pm 9.87^{b}$ & $320.60 \pm 43.70^{\mathrm{b}}$ & $423.66 \pm 24.92^{\mathrm{b}}$ \\
\hline $3 \mathrm{~min}$ & $3240.81 \pm 135.41^{c}$ & $-85.43 \pm 4.48^{c}$ & $234.76 \pm 38.28^{c}$ & $338.82 \pm 13.85^{\mathrm{c}}$ \\
\hline $5 \min$ & $3011.38 \pm 49.34^{d}$ & $-88.27 \pm 9.81^{\mathrm{c}}$ & $197.14 \pm 21.39^{c}$ & $314.00 \pm 25.26^{c}$ \\
\hline
\end{tabular}

${ }^{1)}$ No blanching.

${ }^{2)}$ Values in a column followed by different letters are significantly $(\mathrm{p}<0.05)$ different by Duncan's multiple range test.

Blanching한 연근의 관능평가는 9점 기호척도법으로 수 행하였는데, 신선도, 색감, 외관적 상태, 종합적 기호도에서 blanching 시간이 길어짐에 따라 점수가 낮아지는 경향을 나타내었으나(Table 3), 대조구와 처리구에서 모든 항목에 서 6점 이상의 점수를 받아 blanching 처리가 관능적 품질에 큰 영향을 미치지는 않는 것으로 판단된다. 따라서 blanching 처리가 연근의 물성 등에 다소 영향을 미치나, 연근의 미생물학적 안전성이 보다 중요하기에, 본 연구에 서는 최적 blanching 처리 조건을 $100^{\circ} \mathrm{C}$ 에서 5 분 처리하는 것으로 설정하였다.

Table 3. Sensory properties of the blanched lotus root samples

\begin{tabular}{|c|c|c|c|c|c|}
\hline Samples & Freshness & Color & Appearance & Odor & $\begin{array}{c}\text { Overall } \\
\text { preference }\end{array}$ \\
\hline Control $^{1)}$ & $9.00 \pm 0.00^{22)}$ & $9.00 \pm 0.00^{\mathrm{a}}$ & $9.00 \pm 0.00^{\mathrm{a}}$ & $9.00 \pm 0.00^{\mathrm{a}}$ & $9.00 \pm 0.00^{\mathrm{a}}$ \\
\hline $\begin{array}{l}\text { Blanching } \\
1 \text { min }\end{array}$ & $7.75 \pm 0.46^{b}$ & $7.50 \pm 0.93^{b}$ & $7.50 \pm 0.76^{b}$ & $7.75 \pm 0.46^{b}$ & $8.00 \pm 0.76^{b}$ \\
\hline $3 \mathrm{~min}$ & $7.38 \pm 0.52^{\mathrm{bc}}$ & $7.25 \pm 0.89^{b c}$ & $6.88 \pm 0.83^{b c}$ & $7.63 \pm 0.52^{b}$ & $7.25 \pm 0.46^{c}$ \\
\hline $5 \mathrm{~min}$ & $6.88 \pm 0.35^{\mathrm{c}}$ & $6.38 \pm 0.74^{c}$ & $6.63 \pm 0.74^{\mathrm{c}}$ & $7.38 \pm 0.52^{b}$ & $7.13 \pm 0.35^{\mathrm{c}}$ \\
\hline
\end{tabular}

\section{냉동연근의 품질 분석}

냉동연근의 microstructure 분석 결과(Fig. 1$),-20^{\circ} \mathrm{C}$ 에서 냉동한 연근의 조직 단면 구조는 다른 냉동처리구에 비하여 조직이 많이 파괴된 것을 볼 수 있었는데, 이러한 결과는 완만한 냉동속도로 인하여 세포 밖에서 큰 얼음결정이 형성 되어 조직에 영향을 준 것으로 생각된다(27). 반면에 gas nitrogen convection chamber에서 $-70^{\circ} \mathrm{C}$ 로 냉동한 처리구는 다른 처리구에 비해 대조구와 조직 단면 구조가 가장 유사 함을 보여주었다(Fig. 1). 반면에 $-196^{\circ} \mathrm{C}$ 에서 급속냉동한 시료의 조직 단면 구조는 $-70^{\circ} \mathrm{C}$ 로 냉동한 것에 비해 동결속 도가 너무 빨라 작은 얼음결정의 생성으로 더 조밀하나, 일부 손상된 조직을 보여준다(14,15,28).
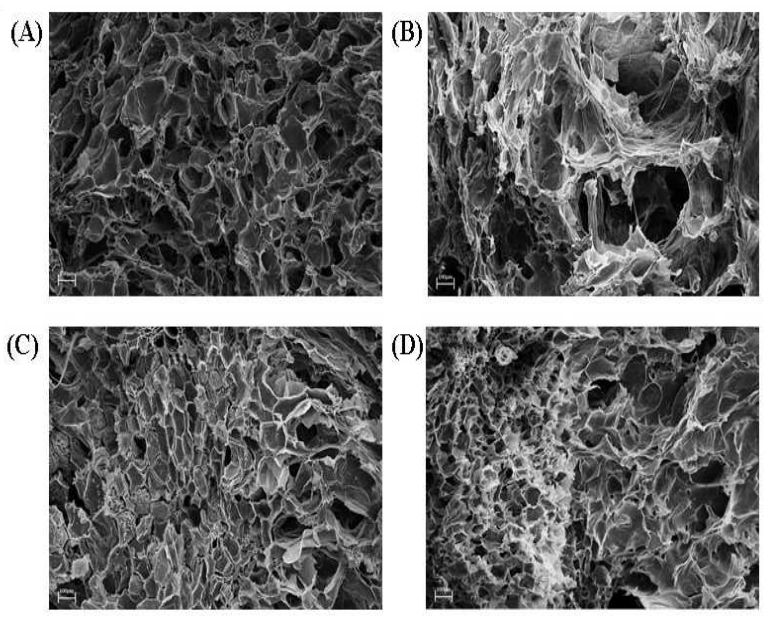

Fig. 1. SEM images of the blanched lotus roots (A) and of the lotus roots frozen at $-20(\mathrm{~B}),-70(\mathrm{C})$, and $-196^{\circ} \mathrm{C}$ (D).

The microstructure was analysed using a scanning electron microscope at $15 \mathrm{kV}$ with $200 \times$ magnification.

Blanching 처리한 연근을 $-20,-70,-196^{\circ} \mathrm{C}$ 에서 냉동한 후 해동하여 연근의 물성을 측정하였는데(Table 4), blanching만 한 연근의 경도가 $3011 \mathrm{~g}$ 이었고, $-20,-70,-19$ $6^{\circ} \mathrm{C}$ 에서 냉동한 연근은 $1170 ~ 1967 \mathrm{~g}$ 으로 $35 \sim 62 \%$ 감소한 것으로 나타났다. 특히 $-20^{\circ} \mathrm{C}$ 에서 냉동한 연근의 경도가 
가장 작게 측정되었는데, 이는 느린 냉동속도 때문에 얼음 결정이 크게 생성되어 조직에 손상을 준 것으로 판단된다. 그리고 $-70^{\circ} \mathrm{C}$ 에 비하여 $-196^{\circ} \mathrm{C}$ 처리구의 경도가 더 작게 측정이 되었는데, 이는 $-196^{\circ} \mathrm{C}$ 에서 냉동된 시료의 경우 액 체질소에 일정시간 dipping하여 냉동시키기 때문에 조직에 물리적 충격이 더 가해져 조직이 파괴된 것으로 판단된다. 본 연구결과는 당근을 각각의 다른 동결방식으로 처리했을 때 조직에 미치는 영향에 대한 연구에서, 완만냉동에 비하 여 급속냉동 한 처리구에서 경도가 높다는 보고와 유사하였 다(29). 한편 점착성은 냉동하지 않은 연근에 비해서 증가했 음을 보여주었으며, $-20^{\circ} \mathrm{C}$ 처리구에서 점착성이 가장 높게 측정되었다. 씹힘성은 냉동하지 않은 연근에 비해 감소하 는 경향을 보였으며 $-20^{\circ} \mathrm{C}$ 처리구에서 50 으로 가장 낮은 측정값을 얻었으며, 3 개의 처리군 중 $-70^{\circ} \mathrm{C}$ 처리구에서 93 으로 씹힘성이 가장 높은 것으로 나타났다. 질김성 또한 $-70^{\circ} \mathrm{C}$ 에서 가장 높은 측정값을 얻어 씹힘성과 비슷한 경향 을 보였다. 이러한 연구결과는 $-70^{\circ} \mathrm{C}$ 에서의 냉동이 가장 좋은 물성을 갖는 것을 보여준다.

Table 4. Changes in texture of the frozen lotus root samples

\begin{tabular}{ccccc}
\hline \multirow{2}{*}{ Samples } & \multicolumn{4}{c}{ Texture parameter } \\
\cline { 2 - 5 } & $\begin{array}{c}\text { Hardness } \\
(\mathrm{g})\end{array}$ & $\begin{array}{c}\text { Adhesiveness } \\
(\mathrm{g} \cdot \mathrm{s})\end{array}$ & Chewiness & Gumminess \\
\hline Control $^{1)}$ & $4590.41 \pm 89.25^{\mathrm{a}} \mathrm{y}$ & $-7.12 \pm 0.28^{\mathrm{a}}$ & $413.84 \pm 42.75^{\mathrm{a}}$ & $1091.00 \pm 56.96^{\mathrm{a}}$ \\
Frozen at $^{-20^{\circ} \mathrm{C}}$ & $1170.27 \pm 99.52^{\mathrm{d}}$ & $-139.30 \pm 4.62^{\mathrm{c}}$ & $50.22 \pm 6.49^{\mathrm{c}}$ & $172.34 \pm 23.81^{\mathrm{b}}$ \\
$-70^{\circ} \mathrm{C}$ & $1967.19 \pm 116.19^{\mathrm{b}}$ & $-98.15 \pm 6.57^{\mathrm{b}}$ & $93.31 \pm 2.84^{\mathrm{b}}$ & $225.61 \pm 12.46^{\mathrm{b}}$ \\
$-196^{\circ} \mathrm{C}$ & $1491.31 \pm 54.27^{\mathrm{c}}$ & $-99.40 \pm 8.57^{\mathrm{b}}$ & $83.54 \pm 6.04^{\mathrm{bc}}$ & $192.49 \pm 10.26^{\mathrm{b}}$ \\
\hline
\end{tabular}

${ }^{1)}$ No blanching.

${ }^{2)}$ Values in a column followed by different letters are significantly $(\mathrm{p}<0.05)$ different by Duncan's multiple range test.

항산화능 측정은 냉동 후 해동된 연근의 DPPH radical scavenging activity 측정한 결과, 대조구가 $78 \%$ 인 반면에 냉동 처리구는 $20 \%$ 가 감소한 $58 \%$ 를 나타내었는데 처리구 간에는 유의적인 차이를 보이지 않았다(Table 5). 또한 FRAP assay 결과, 대조구가 $1.28 \mathrm{mg} \mathrm{GAE} / \mathrm{g}$ sample이었고, 각각의 냉동 처리구는 $0.74 ~ 0.79 \mathrm{mg} \mathrm{GAE} / \mathrm{g}$ sample의 측정
값으로 감소하였으며 처리구간에는 유의적인 차이가 없었 다. 이러한 결과는 양배추를 blanching 하여 장기간 냉동저 장 중에 FRAP assay로 항산화능을 분석한 연구에서, 신선 한 양배추에 비하여 blanching을 거쳐 냉동처리한 양배추의 항산화능이 감소한 결과와 비슷한 경향을 보였다(30).

총 페놀 함량은 대조구와 비교 시 13 16 mg GAE/100 $\mathrm{g}$ sample이 감소한 30 33 mg GAE/100 g sample의 측정값을 얻었는데, $-70,-196^{\circ} \mathrm{C}$ 처리구간에는 유의적인 차이를 보이 지 않았고, $-20^{\circ} \mathrm{C}$ 처리구는 $30 \mathrm{mg} \mathrm{GAE} / 100 \mathrm{~g}$ sample으로 가장 낮았다. 이러한 결과는 수분손실률과 연관 지어 설명 할 수 있는데, 본 연구에서 수분손실률을 측정해 본 결과, $-20^{\circ} \mathrm{C}$ 에서 동결한 연근의 수분손실이 $3.73 \%$ 로 동결처리구 중에 가장 높게 측정되었다(Table 5). 이러한 결과는 $-20^{\circ} \mathrm{C}$ 처리구가 다른 처리구에 비해 해동과정에서 많은 수분손실 로 인하여 가용화된 페놀계 성분이 수분과 함께 조직 밖으 로 빠져 나와 총 페놀 함량이 낮게 측정된 것으로 판단된다 (31).

따라서 본 연구에서 냉동 후 해동된 시료의 품질 측정 결과, gas nitrogen convection chamber에서 $-70^{\circ} \mathrm{C}$ 로 냉동하 는 것이 $-20,-196^{\circ} \mathrm{C}$ 에서 냉동하는 것에 비해 고품질 냉동연 근을 생산하기 위한 적절한 냉동방법이라고 판단된다.

\section{요 약}

본 연구는 냉동연근의 최적 제조 공정을 위하여 수행하 였다. 냉동 전처리로 blanching 하고, $-20,-70,-196^{\circ} \mathrm{C}$ 각각 다른 냉동온도에서 동결한 냉동연근의 품질을 측정하였다. 최적 blanching 조건은 미생물 수, 물성, 총 페놀 함량, 관능 평가 등의 결과를 바탕으로, $100^{\circ} \mathrm{C}$ 에서 5 분간 처리로 설정 하였다. 여러 냉동조건에서 동결한 연근의 SEM 사진을 비교한 결과, $-20^{\circ} \mathrm{C}$ 에서 동결한 연근의 조직이 가장 많이 파괴되었고 $-70^{\circ} \mathrm{C}$ 에서 동결한 연근의 조직 단면 구조가 대조구와 가장 유사하였다. 항산화능은 동결 시 감소하는 경향을 나타냈고, 처리구간에 유의적인 $(\mathrm{p}<0.05)$ 차이는 없 었다. 총 페놀 함량은 모든 냉동연근에서 감소하는 경향을 보였는데 $-20^{\circ} \mathrm{C}$ 에서 가장 낮았고, drip loss 또한 $-20^{\circ} \mathrm{C}$ 에서

Table 5. Antioxidant activities and TPC and drip loss values of the frozen lotus root samples

\begin{tabular}{ccccc}
\hline Samples & $\begin{array}{c}\text { Scavenging activity on DPPH } \\
\text { radicals (\%) }\end{array}$ & $\begin{array}{c}\text { FRAP } \\
\text { (mg GAE/g sample) }\end{array}$ & $\begin{array}{c}\text { Total phenolic content } \\
\text { (mg GAE/100 g sample) }\end{array}$ & Drip loss (\%) \\
\hline Control ${ }^{1)}$ & $77.58 \pm 0.23^{\mathrm{al})}$ & $1.28 \pm 0.06^{\mathrm{a}}$ & $46.16 \pm 1.67^{\mathrm{a}}$ & - \\
Frozen at $-20^{\circ} \mathrm{C}$ & $57.78 \pm 0.28^{\mathrm{b}}$ & $0.78 \pm 0.06^{\mathrm{b}}$ & $30.24 \pm 0.12^{\mathrm{c}}$ & $3.73 \pm 0.21^{\mathrm{a}}$ \\
$-70^{\circ} \mathrm{C}$ & $58.14 \pm 0.40^{\mathrm{b}}$ & $0.74 \pm 0.01^{\mathrm{b}}$ & $33.04 \pm 1.63^{\mathrm{b}}$ & $2.70 \pm 0.26^{\mathrm{b}}$ \\
$-196^{\circ} \mathrm{C}$ & $58.10 \pm 0.11^{\mathrm{b}}$ & $0.79 \pm 0.06^{\mathrm{b}}$ & $32.09 \pm 0.43^{\mathrm{bc}}$ & $2.65 \pm 0.21^{\mathrm{b}}$ \\
\hline
\end{tabular}

\footnotetext{
${ }^{1)}$ No blanching.
}

${ }^{2)}$ Values in a column followed by different letters are significantly $(\mathrm{p}<0.05)$ different by Duncan's multiple range test. 
$3.73 \%$ 로 가장 높았다. 따라서 본 연구 결과, $-20^{\circ} \mathrm{C}$ 에서의 일반적인 냉동보다는 gas nitrogen convection chamber에서 의 $-70^{\circ} \mathrm{C}$ 로 동결하는 것이 고품질의 냉동연근을 생산할 수 있는 최적 냉동방법이라고 판단된다.

\section{References}

1. Bae MJ, Kim SJ, Ye EJ, Nam HS, Park EM (2008) Study on the chemical composition of lotus root and functional evaluation of fermented lotus root drink. Korean J Food Culture, 23, 222-227

2. Park KJ, Jeong JW, Lim JH, Kun KB (2008) Quality changes in peeled lotus roots immersed in electrolyzed water prior to wrap- and vacuum-packaging. Korean J Food Preserv, 15, 622-629

3. XU S, Shoemaker CF (1986) Gelatinization properties of Chinese water chestnut starch and lotus root starch. J Food Sci, 51, 445-449

4. Du J, Fu Y, Wang N (2009) Effects of aqueous chlorine dioxide treatment on browning of fresh-cut lotus root. LWT-Food Sci Technol, 42, 654-659

5. Xing Y, Li X, Xu Q, Jiang Y, Yun J, Li W (2010) Effects of chitosan-based coating and modified atmosphere packaging (MAP) on browning and shelf life of fresh-cut lotus root (Nelumbo nucifera Gaerth). Innov Food Sci Emerg Technol, 11, 684-689

6. Kim HB, Chung HS, Moon KD (2014) Browning inhibition of fresh-cut lotus roots by blanching in Glycyrrhiza glabra L. and Astragalus membranaceus Bunge extracts. Korean J Food Preserv, 21, 151-156

7. Lee YJ, Lee HO, Kim JY, Kwon KH, Cha HS (2011) Quality characteristics of frozen Doraji (Platycodon grandiflorum) according to various blanching treatment conditions. Korean J Food Preserv, 18, 661-668

8. Patras A, Tiwari B, Brunton N (2011) Influence of blanching and low temperature preservation strategies on antioxidant activity and phytochemical content of carrots, green beans and broccoli. LWT-Food Sci Technol, 44, 299-306

9. Negi PS, Roy SK (2000) Effect of blanching and drying methods on $\beta$-carotene, ascorbic acid and chlorophyll retention of leafy vegetables. LWT-Food Sci Technol, 33, 295-298

10. Castro SM, Saraiva JA, Lopes-da-Silva JA, Delgadillo I, Loey AV, Smout C, Hendrickx, M (2008) Effect of thermal blanching and of high pressure treatments on sweet green and red bell pepper fruits (Capsicum annuum L.). Food Chem, 107, 1436-1449

11. Park JH, Hong SI, Jeong MC, Kim DM (2013) Effect of mild heat and organic acid treatments on the quality of fresh-cut lotus roots. Korean J Food Preserv, 20, 23-29

12. Parreno WC, Torres MD (2005) Handbook of frozen food processing and packaging, CRC Press, New York, USA, p 391-396

13. Roy S, Taylor T, Kramer H (2001) Textural and ultrastructural changes in carrot tissue as affected by blanching and freezing. J Food Sci, 66, 176-180

14. Chassagne-Berces S, Poirier C, Devaux M-F, Fonseca F, Lahaye M, Pigorini G, Giraul C, Marin M, Guillon F (2009) Changes in texture, cellular structure and cell wall composition in apple tissue as a result of freezing. Food Res Int, 42, 788-797

15. Park SJ, Al Mijan M, Song KB (2014) Quality changes in Pteridium aquilinum and the root of Platycodon grandiflorum frozen under different conditions. Int $\mathbf{J}$ Refrig, 43, 90-96

16. Rumbaoa RGO, Cornago DF, Geronimo IM (2009) Phenolic content and antioxidant capacity of Philippine sweet potato (Ipomoea batatas) varieties. Food Chem, 113, 1133-1138

17. Kim SJ, Cho AR, Han JJ (2013) Antioxidant and antimicrobial activities of leafy green vegetable extracts and their applications to meat product preservation. Food Control, 29, 112-120

18. Benzie IFF, Strain JJ (1996) The ferric reducing ability of plasma (FRAP) as a measure of antioxidant power : the FRAP assay. Anal Biochem, 239, 70-76

19. Kim MH, Kim YJ, Kim KS, Song YB, Seo WJ (2009) Microbial changes in hot peppers, ginger, and carrots treated with aqueous chlorine dioxide or fumaric acid. Korean J Food Preserv, 16, 1013-1017

20. Han Y, Floros J, Linton R, Nielsen S, Nelson E (2001) Response surface modeling for the inactivation of Escherichia coli O157:H7 on green peppers (Capsicum annuum L.) by chlorine dioxide gas treatments. J Food Protect, 64, 1128-1133

21. Chang MS, Kim JG, Kim GH (2011) Quality characteristics of fresh-cut lotus roots according to the temperature of the wash water. Korean J Food Preserv, 18, 288-293

22. Breidt F, Hayes J, Fleming H (2000) Reduction of microflora of whole pickling cucumbers by blanching. J Food Sci, 65, 1354-1358 
23. Kim JG, Choi ST, Pae DH (2009) Effect of heat treatment and dipping solution combination on the quality of peeled potato 'Jopung'. Korean J Hort Sci Technol, 27, 256-262

24. Ralph GK, Sascha B, Gudrun W, Walter PH, Reinhold C (2005) Quality of minimally processed carrots as affected by warm water washing and chlorination. Innov Food Sci Emerg, 6, 351-362

25. Lee HS (1995) The measurement methods of the textural characteristics of fermented vegetable. Korean J Soc Food Sci, 11, 83-91

26. Amin I, Norazaidah Y, Hainida K (2006) Antioxidant activity and phenolic content of raw and blanched Amaranthus species. Food Chem, 94, 47-52

27. Delgado A, Rubiolo A (2005) Microstructural changes in strawberry after freezing and thawing processes. LWT-Food Sci Technol, 38, 135-142

28. Chassagne-Berces S, Fonseca F, Citeau, M, Marin M (2010) Freezing protocol effect on quality properties of fruit tissue according to the fruit, the variety and the stage of maturity. LWT-Food Sci Technol, 43, 1441-1449

29. Van Buggenhout S, Lille M, Messagie I, Van Loey A, Autio K, Hendrickx M (2006) Impact of pretreatment and freezing conditions on the microstructure of frozen carrots : quantification and relation to texture loss. Eur Food Res Technol, 222, 543-553

30. Volden J, Bengtsson GB, Wicklund T (2009) Glucosinolates, L-ascorbic acid, total phenols, anthocyanins, antioxidant capacities and colour in cauliflower (Brassica oleracea L. ssp. botrytis) : effects of long-term freezer storage. Food Chem, 112, 967-976

31. Holzwarth M, Korhummel S, Carle R, Kammerer DR (2012) Evaluation of the effects of different freezing and thawing methods on color, polyphenol and ascorbic acid retention in strawberries (Fragaria $\times$ ananassa Duch). Food Res Int, 48, 241-248 